This work is licensed under a Creative Commons Attribution 4.0 International License.

Ovaj rad dostupan je za upotrebu pod međunarodnom licencom Creative Commons Attribution 4.0.

\title{
Ivo Pranjković
}

\section{O RIJEČIMA NEGO, NO, VEĆ, JOŠ I TEK ${ }^{1}$}

dr. sc. Ivo Pranjković, Filozofski fakultet, ivo.pranjkovic@zg.t-com.hr, Zagreb

izvorni znanstveni članak

UDK 811.163.42'366.5

$811.163 .42 ' 367.7$

811.163.42'367.634

rukopis primljen: 13. 2. 2018.; prihvaćen za tisak: 29. 3. 2018.

U prilogu je riječ gramatičkim i pragmatičkim svojstvima te o podrijetlu, uporabi i značenjima u mnogo čemu srodnih „malih riječi” nego, no, već, još $i$ tek. Posebno se analizira njihova poraba u značenjima uspoređivanja (npr. Bolje je nego prije), u pragmatičkim značenjima vremenske naravi, osobito u označavanju događanja koji se odvijaju prije (npr. Već su stigli ili Još nisu stigli) ili poslije govornikova očekivanja (npr. Tek su danas doputovali). I napokon razmatra se uloga tih riječi u funkciji veznika suprotnih rečenica (npr. Nismo im pisali, već smo ih nazvali telefonom) ili veznih sredstava na razini teksta (npr. Tu ne raste ništa. Tek kamenje se golo plavi).

Ključne riječi: gramatikalizirane riječi; pragmatička svojstva; podrijetlo; kompariranje; vremenska značenja; suprotnost

U ovom će prilogu biti riječi o gramatičkim i pragmatičkim svojstvima, podrijetlu i značenjima u mnogo čemu sličnih gramatikaliziranih odnosno pragmatikaliziranih riječi nego, no, već, još i tek, posebice u struktu-

1 Kako su gramatička (posebice sintaktička) i pragmatička svojstva „malih riječi” jedna od tema koja mi je posebno bliska te kako sam dio priloga na tu temu objavio u Rijeci (riječ je o prilozima „Vezničko i nevezničko da u hrvatskome jeziku” te „Zamjenica, prilog, čestica i veznik što", koji su tiskani u zbornicima Riječki filološki dani 7 i 8, usp. Pranjković 2008 i 2010), smatrao sam primjerenim baš na tu temu ponuditi i ovaj prilog povodom jubileja (30. obljetnice izlaženja) uglednog riječkog filološkog časopisa Fluminensia. 
rama u kojima te riječi funkcioniraju kao čestice, kao veznici odnosno kao dijelovi složenih veznika ili kao vezna sredstva na razini teksta (konektori).

\section{Čestica i veznik nego}

Riječ nego, koja se javlja(la) i u likovima neg, negoli, negli, neže i sl., sastavljena je od negacije ne i čestice go. Za tu česticu u Akademijinu se Rječniku kaže sljedeće: „ovo go ili že je osobita partikula, koja se dodaje gdjekojim riječima, imamo je na pr. u jer ili jere, koje je postalo od starijega ježe (t.j. je $\check{z} e$ ), u ondar, tadar (od starijega ondare, tadare, a to je od još starijega ondaže, tadaže. Da že ispred e, a iza kratkog vokala katkad prelazi u $r$, te (sic!) se vidi i u nebore (mjesto nebože), moreš, more (pored možeš, može)". Također se kaže da je prvobitno značenje riječi nego modalno odnosno poredbeno, tj. da znači „kao, kako”, ${ }^{2}$ da su se iz toga modalnoga značenja razvila i druga značenja te da se ta riječ, u likovima nego, neže ili neželi nalazi i u drugim slavenskim jezicima, u staroslavenskom, slovenskom, ruskom i češkom (ARj VII: 835).

Spomenuto poredbeno značenje i u starijim stadijima razvoja hrvatskoga jezika i u suvremenom jeziku posebno dolazi do izražaja kada ta riječ „služi za izricanje načina iza komparativa i iza riječi, koje u neku ruku imaju komparativno značeńe", npr. Sluga nije veći nego gospodar ili Nijedna zloća na svijetu nije gora negoli nespoznanje (ARj VII: 836).

Rjeđe se nego može javiti i između dvaju komparativa, npr. Sretniji je nego pametniji (usp. ARj VII: 837). U starijem jeziku komparativno nego katkada se rabilo i iza superlativa, npr. Zaštićuješ najvećega neprijatelja nego imaš (usp. ARj VII: 840). U suvremenom se jeziku takve konstrukcije više ne susreću.

Kad nego dolazi iza priložnoga komparativa prije, kao npr. u rečenicama tipa Prije bi zvijezde prebrojio nego vojsku cara Vasilija (usp. ARj VII: 839), redovito se događa da se taj komparativ dodatno gramatikalizira pa zajedno s nego čini složeni veznik prije nego ili prije nego što, npr. Nemojte ništa poduzimati prije nego se posavjetujete s liječnikom ili Pojavili su se prije nego što ih je itko očekivao. Takve rečenice čine vrstu vremenskih rečenica kojima se izražava poslijevremenost (posteriornost). ${ }^{3}$

2 Takvo značenje (poredbeno odnosno gradacijsko) susrećemo npr. u danas posve zastarjelim primjerima tipa Nijesam ga ni vidio, a negoli ulovio (usp. ARj VII: 836).

3 Opširnije o takvim rečenicama usp. u Silić i Pranjković 2005: 337. 
U starijem jeziku bile su relativno obične rečenice toga tipa i s priložnim komparativom poslije, koji se također mogao dodatno gramatikalizirati pa s riječju nego činiti složeni veznik poslije nego ili poslije nego što, npr. Treći dan posli nego uhode dođoše, diže Josue puk svoj ili Tri brata redovnika umriše posli nego što se pričestiše (usp. ARj VII: 839). U suvremenom jeziku takve su rečenice, ako se uopće pojave, obilježene kao izrazito rijetke i/ili zastarjele.

Od ostalih riječi koje imaju (i) komparativno značenje osobito je u konstrukcijama s česticom nego čest glagol voljeti (koji u mnogim kontekstima dolazi u značenju „više voljeti”), npr. Volim s dragim po gori hoditi neg $s$ nedragim po dvoru šetati (usp. ARj, nav. mj.) ili u (danas ponešto obilježenim) primjerima tipa Vole tebi pokloniti nego drugome prodati.

$\mathrm{U}$ dosad navedenim primjerima (osim ovih s glagolom voljeti) nego dolazi među riječima i/ili oblicima odnosno među pojedinim članovima rečeničnoga ustrojstva. Puno rjeđe, pogotovo u suvremenom jeziku, iza takvoga nego slijedi cijela surečenica, npr. Ljepši svati nisu projezdili nego danas svati projezdiše (usp. ARj VII: 837). Takve surečenice s dijelom struktura u kojima dolaze komparativne riječi danas se povezuju složenim veznicima nego što, npr. Ispalo je bolje nego što smo se nadali, ${ }^{4}$ nego da, npr. Ispalo je bolje nego da smo se unaprijed dogovorili, ${ }^{5} \mathrm{ili}$ nego kad, npr. Hladnije je nego kad je padala kiša.

Poredbeno nego često dolazi i iza pitanja, ponajprije afirmativnih. Takva pitanja mogu sadržavati i komparative ili riječi poredbenoga značenja, npr. Što je čovjeku korisnije neg ljubovca blage ćudi? (usp. ARj VII: 844) ili Komu je teže nego meni?, ali mogu biti i bez takvih riječi, npr. Komu ću biti zahvalan nego roditeljima? ili Kud će suza neg na oko? ${ }^{6}$

Vrlo često, i u starijem i u suvremenom hrvatskom jeziku, nego dolazi u službi konjunktora suprotnih nezavisnosloženih rečenica, i to u onoj vrsti takvih rečenica u kojima se susreće tip suprotnosti poznat pod imenom korektura, npr. Nisu došli, nego su se javili telefonom. U takvim je rečenicama

4 Rečenice bez veznoga što tipa Ispalo je bolje nego smo se nadali u suvremenom su jeziku obilježene kao rijetke, a ne preporučuju se ni normativno.

5 Veznik nego što dolazi u rečenicama koje označuju izvjesnost (faktivnost), a nego da u rečenicama koje označuju neizvjesnost (hipotetičnost, nefaktivnost). Usp. o tome i Pranjković 2013: 244-255.

6 U takvim upitnim rečenicama poredbene se riječi često na neki način pretpostavljaju, osobito riječi tipa drugi, drugdje ili sl., usp. Komu ću drugome biti zahvalan nego roditeljima? ili Kud će suza (drugdje) neg na oko? 
prva surečenica obvezatno niječna ${ }^{7}$ i obvezno je prvom mjestu. Obrnuti redoslijed surečenica posve je negramatičan, usp. ${ }^{*} J a v i l i$ su se telefonom, nego nisu došli ili *Nego su se javili telefonom, nisu došli. Prvom se surečenicom niječe nešto što se drugom (bar donekle) korigira, tj. afirmira (otud i naziv korektura). Takav tip suprotnosti može se uspostavljati među pojedinim članovima rečeničnoga ustrojstva, npr. među subjektima, usp. Nije došao Ivan, nego Petar, među objektima, usp. Ne piše pjesme, nego pripovijesti, među priložnim oznakama, usp. Ne dolazi danas, nego sutra itd. Dakako, takav je odnos vrlo čest i među (potpunim) surečenicama, npr. Lemozine prosit ne ktijaše, nego linac veliki bijaše (usp. Arj VII: 841) ili Ne spavaju, nego se goste na izletištu i sl. Takvo vezničko nego u pravilu je zamjenjivo vezničkim već, npr. Ne spavaju, već se goste na izletištu.

Vezničko nego u suvremenom jeziku vrlo se često javlja u sastavu složenoga veznika ne samo ... nego $i$, koji dolazi u gradacijskim rečenicama korelativnog tipa, npr. Ovamo dolaze ne samo stranci nego i domaći. U takvim (nezavisnosloženim) rečenicama suprotni odnos prelazi u gradacijski uz pomoć restriktivne čestice samo i pojačajne (intenzivne) čestice $i$. Čestica samo naime umanjuje komunikacijsku važnost riječi i/ili oblika ispred kojih stoji i time relativizira niječnu tvrdnju u prvoj surečenici takvih složenih rečenica. S druge strane pojačajna čestica $i$ (intenzifikator) ima suprotnu funkciju. Ona naime ističe element ispred kojega stoji i time mu povećava komunikacijsku važnost (opširnije o tome usp. Kovačević 1987: 225-236 te Silić i Pranjković 2005: 326-327; o čestici samo u takvim strukturama usp. Pranjković 2016: 145-148).

Riječ nego ima specifičnu funkciju i značenje u dijalozima kad se javlja zajedno s relativnim riječima kao što su što ili kako, pri čemu se donekle frazeologizirani izričaji nego što ili nego kako javljaju kao naglašeno potvrdni odgovori sugovornika na neku govornikovu tvrdnju. Imaju naime značenje slično značenju čestice itekako, npr. A. Trebalo bi ih nagovoriti da nam se pridruže. B. Nego što! ili A. Ja bih to ocijenio negativno. B. Nego kako!

7 U starijem jeziku suprotni veznik nego mogao je dolaziti, ali vrlo rijetko, i iza afirmativnih surečenica, npr. Mala fala duždu od Mletaka, mala fala caru čestitome, nego fala Kraljevome Marku (usp. ARj VII: 842). U jednom dijelu takvih rečenica nego kao da gubi nešto od značenja suprotnosti i približava se značenju izuzimanja, tj. značenju čestice (ili prijedloga) osim, npr. Sve jest ispraznost nego ljubiti samoga Boga (usp. ARj VII: 843). 


\section{Čestica, veznik i konektor no}

Čestica no podrijetlom je, a dijelom i uporabno srodna čestici odnosno uzviku nu, posebno kad dolazi na početku rečenice, npr. No, sinko, kako je bilo? (ARj VIII: 212) ili No sad bi zbilja bilo dosta! U Akademijinu Rječniku tvrdi se da no nije postalo od nego, kao što su mislili Daničić i Miklošič, ali se čini (bar meni) da je moglo postati i tako, tj. svojevrsnim „sažimanjem” čestice nego bar u onim primjerima u kojima no dolazi kao poredbena čestica i u kojima je posve zamjenjiva s nego, npr. Bolje se pametno skriti no sramotno prikazati (usp. ARj VIII: 214). ${ }^{8}$ To bi vrijedilo i za primjere u kojima se poredbeno no javlja među riječima odnosno među dijelovima rečeničnoga ustrojstva, posebice imenskoga tipa, npr. Ivan je uredniji no Petar ili Češce igraju srijedom no subotom, s tim da su takve konstrukcije u suvremenom hrvatskom jeziku ili obilježene kao rijetke ${ }^{9}$ ili imaju ograničenu porabu, pa su npr. češće u naslovima, reklamama i sl., usp. Deserti bolji no ikad.

Mislim da bi se nešto slično za česticu no moglo reći i kad dolazi u ekskluzivnom značenju i kad je također posve zamjenjiva s nego, npr. Evo nemam nikoga od roda no jednoga Bogom pobratima (usp. ARj VIII: 213).

U suvremenom jeziku no se međutim najčešće susreće u službi veznika nezavisnosloženih suprotnih rečenice, u kojima ima ponajprije dopusno značenje, tj. značenje posve slično značenju veznika ali, npr. Ciganin počne jesti, no domaćin mu ne dade (usp. ARj VIII: 213) ili Više sam puta nazivao, no nitko se nije javljao. U takvim je složenim rečenicama prva surečenica obično afirmativna. $U$ toj službi veznik no nije, bar ne u suvremenom jeziku, zamjenjiv s nego, usp. *Više sam puta nazivao, nego se nitko nije javljao.

Međutim u većem dijelu suprotnih rečenica s niječnom prvom surečenicom no je posve zamjenjivo veznikom nego, što znači da je takvim rečenicama svojstveno spomenuto značenje tzv. korekture koje je konjunktoru

8 Drugim riječima, čini se da bi možda, bar po podrijetlu, trebalo razlikovati dva različita no. Jedno bi bilo uzvične naravi i u izravnoj vezi s (uzvičnom) česticom $n u$, a drugo bi bilo poredbene ili suprotne naravi i u vezi s vezničkim nego. Tome u prilog ide i činjenica da se starija čestica nu nikad nije rabila u poredbenom ili suprotnom značenju, usp. npr. *Ivan je uredniji nu Petar ili sl.!?

9 Takve konstrukcije mogu biti i regionalno obilježene, pa su npr. tipičnije za područje Crne Gore ili istočne Hercegovine negoli za ostala štokavska područja. 
nego primarno, npr. Blago nije ni srebro ni zlato, no je blago što je srcu drago (usp. ARj VIII: 213) ili Nije dolazio niti pisao, no javio se telefonom.

Za razliku od nego no se vrlo rijeko upotrebljava iza pitanja, npr. Komu je teže no meni? Isto tako rijetko je i u sastavu složenih veznika, npr. Više sam kupio no što sam namjeravao, Volim biti točan no da me opominju ili Bolje smo se osjećali no kad smo bili u Dubrovniku. Takve su rečenice u suvremenom jeziku, ako se i upotrijebe, u pravilu obilježene kao rijetke i/ili regionalne.

No za razliku od nego no je u suvremenom jeziku postalo vrlo često u službi suprotnoga konektora, tj. veznoga sredstva adverzativnoga značenja na razini teksta, sličnoga konektoru međutim, npr. Sastali smo se što smo mogli prije i o svemu temeljito porazgovarali. No ni to nije dalo rezultata kakve smo očekivali (usp. o tome Silić i Pranjković 2005: 326). ${ }^{10}$ Takvo no nikada nije zamjenjivo s nego.

\section{Čestica i veznik već}

Za česticu i/ili veznik već u Akademijinu se Rječniku kaže da je prilog i veznik te da je podrijetlom „zapravo supletivni komparativ neutr. veće pridjevu velik” (ARj XX: 651). U početku je imala oblik veće, pa se poslije počela javljati s „ispuštenom deiksom” -e (Skok 1973: 371). Postupnom gramatikalizacijom već je postalo „vezica suprotnosti upravo kao magis u romanskim jezicima”. U kajkavskom narječju ta se čestica rabi i kao „prilog za tvorenje komparativa" (usp. Skok, nav. mj.), npr. več kriv = krivlji. Ta se čestica javlja i u prefiksalnim tvorenicama odveć ili preveć, a, uglavnom u starijem jeziku, i u tvorenicama sa sufiksom -ma u obliku većma (Skok nav. mj.). ${ }^{11}$

Značenje je čestice već vezano za vrijeme, znači „skoro, ubrzo; u pravo vrijeme, ne prekasno, prije nego se očekuje" (ARj XX: 651). Ta riječ ima izrazitu pragmatičku funkciju jer je temeljno njezino značenje obavijest o tome da se ono o čemu je riječ u rečenici događa, da se dogodilo ili događalo odnosno da će se dogoditi ili događati prije očekivanja, ponajprije prije govornikova očekivanja, npr. Da je snijeg, već bi okopnio, labudovi već bi poletjeli ili Dosta, već smo vas razumjeli! (ARj XX: 652). Usp. također u tom značenju i primjere Zar ste već sve pojeli? ili Već je kasno, pođimo na spavanje!

\footnotetext{
10 Takvo se no nalazi i na početku ovoga paragrafa.

11 Sličnoga je podrijetla i tvorenica veoma, a u starijem jeziku i (danas posve zastarjele) tvorenice boljma, lišma ili manjma (usp. Skok, nav. mj.)
} 
U suvremenom jeziku riječ već česta je i u ulozi pojačajne čestice (intenzifikatora), kojom se ističe sadržaj iskaza ili njegova dijela, npr. Vi ćete se već morati suočiti s time ili Ako je već tako, zašto ih ne bismo poslušali? (usp. o tome u Halilović, Palić i Šehović 2010: 1425). Slične je naravi i čestica već (ili već $i$ ) koja osobito često dolazi uz imenske skupine sa zamjeničkim pridjevom sam, $-a,-o$, npr. Ljuti me već sama pomisao na to (usp. Anić 1998: 1290) ili Mnogima će biti zanimljiv već i sam nagovještaj takvih promjena.

U starijem jeziku (vrlo često i u obliku veće) već je imalo i značenje kakvo danas ima komparativ više, npr. Gdi padoše, već se ne digoše ili Ja se, braćo, već ženiti neću (usp. ARj XX: 653). U suvremenom su jeziku takve konstrukcije obilježene kao izrazito zastarjele. To pogotovo vrijedi za konstrukcije tipa Mlađega sina već ljubljaše od inih (ARj, nav. mj.) ili Meni nema već dvadeset godina (ARj XX: 654) u kojima čestica već ima izrazito komparativno značenje.

Nešto slično vrijedi i za one konstrukcije u kojima bismo u suvremenom jeziku umjesto već upotrijebili česticu još, npr. Ne znam spominju li ih već ili Tko zna jesu li već živi? (ARj XX: 653).

Budući da je komparativnoga podrijetla, očekivano je da se već upotrebljava i kao poredbena čestica posve sinonimna s česticom nego, samo je ona znatno rjeđa i obilježena kao ponešto arhaična i/ili regionalna, npr. Volio bih je poljubiti već sa carem večerati (ARj XX: 655) ili Ona je zadovoljnija već ti i ja.

Čestica već može također označavati i gotovost radnje ili zbivanja vezanih za prošlost, npr. To sam već doživio ili O tome smo već razgovarali.

U primjerima tipa Oni će se već dogovoriti ili Ti ćeš to već nekako riješiti čestica već naglašava specifičan aspekt buduće radnje s nijansom vjerojatne mogućnosti vršenja takve radnje odnosno eventualnosti. Takvo je značenje blisko značenju prijedložno-padežnoga izraza $s$ vremenom, ali s dodatno naglašenom modalnošću odnosno eventualnošću.

U sastavu složenog vremenskoga veznika prije već ili prije već što, za razliku od složenih veznika prije nego ili prije nego što koji su u suvremenom jeziku obični i vrlo česti, već je posve zastarjelo i uopće se više ne rabi u suvremenom jeziku, usp. Udavača se mora oblačiti prije već što pođe na vjenčanje (ARj, nav. mj.).

Pogotovo su zastarjele složene zavisnosložene rečenice povezane složenim (suprotno-uvjetnim) veznikom već ako, koje su u starijim stadijima razvoja jezika bile izrazito česte, npr. Neće biti raja baštenici, već ako se 
budu pokoriti, Neće iz nje izaći, već ako ga odvedu ili I da ti u ovi dom više povratka ne bude, već ako gostom kad navratiš (ARj XX: 656). ${ }^{12}$

U još većoj mjeri rečeno vrijedi za složene rečenice povezane složenim veznikom već ako da, npr. Pošten se čovjek ne može povampiriti, već ako da preko njega mrtva preleti kakva tica (ARj 657). U suvremenom jeziku, u kojem se konstrukcije s već ako da više uopće ne susreću, na tom bi se mjestu uporabio veznik osim da.

Kako je poredbeno značenje vrlo blisko značenju suprotnosti, nije neočekivano da se već rabi i kao veznik suprotnih rečenica, također sinoniman s veznikom nego, ali obilježen kao rjeđi, posebno rijedak u primjerima u kojima je drugi dio poredbene konstrukcije imenskoga tipa, npr. Nisam zahvalio Ivanu, već Petru ili Nismo kupili rajčica, već krastavaca. Međutim puno je običnija poraba toga veznika među potpunim surečenicama suprotnih rečenica, npr. Nismo išli na izlet, već smo se dogovorili da se nađemo na večeri (usp. o tome Silić i Pranjković 2005: 326).

I napokon u vezi s česticom već treba spomenuti i dijelom frazeologizirani izričaj već jednom (ili već jedanput) koji se obično upotrebljava u iskazima s imperativom, npr. Recite već jednom, Poduzmi već jednom nešto $u$ životu i sl. Takvim se izričajima u pravilu izražava kakvo govornikovo nestrpljenje vezano za nešto što sugovornik (još) nije učinio, ali je po mišljenju govornika trebao učiniti (usp. Halilović, Palić i Šehović 2010: 1425).

Frazeologizirane je naravi i izričaj već prema tome, koji ima uvjetno ili uvjetno-alternativno značenja, pa je donekle sinoniman s izrazima tipa ovisno o tome, zavisno od toga ili sl., npr. Razgledat ćemo ili samo Dubrovnik ili i Dubrovnik i Cavtat, već prema tome koliko budemo imali vremena (usp. o tome i Anić 1998: 1290).

12 U suvremenom jeziku umjesto već ako dolazi isključno-uvjetni veznik osim ako, usp. Neće iz nje izaći, osim ako ga (ne) odvedu. 


\section{Čestica (i prilog) još}

Čestica jos ${ }^{13}$ ili, u starijem jeziku, jošte „ističe da preko ńečega što se kaže ili misli ima što drugo čemu se nije bilo nadati” (ARj IV: 659). Skok tu česticu opisuje kao „prilog za pojačavanje trajanja” (Skok, 1971: 783-784). Postala je od praslavenskoga oblika ješte, a susrećemo je u sličnim oblicima u ruskom, slovenskom, češkom i bugarskom jeziku. U Akademijinu Rječniku naglašava se da promjena ješte u još ili jošte „nije jasna, ako se i nalazi u drugijeh sličnijeh primjera (kao jelha i joha, jemuža i jomuža, joj mj. jej” (ARj, nav. mj.). Od oblika ješte najprije je postalo jošte, a u starijem jeziku susretali su se još i likovi jošt, jošter, joštera i sl. Postanje same riječi nije jasno. Neki pretpostavljaju da je postalo „od korijena za treće gramatikalno lice [...] ali odakle je nastavak šte (isprva ske?) ne zna se" (ARj, nav. mj.). A. Vaillant tvrdio je da je još podrijetlom zapravo „priloški neutrum od pridjeva *jestb = bio”, ali to mišljenje Skok smatra „imaginarnim” (usp. Skok, nav. mj.).

Primarno je značenje čestice još, kao i čestice već, vezano za vrijeme. Označuje naime da „ńešto ne prestaje, da ńešto još traje”. To da nešto (i dalje) traje može se odnositi i na sadašnjost, npr. Kralj ki pravdom još se slavi ili Još nije u mirovini, i na prošlost, npr. Sestra je njemu još u zipki carstvo prorokovala (ARj, nav. mj.) ili Još jučer smo se o tome dogovorili, i na budućnost, npr. Čekaj, još će doć danak taj (ARj, nav. mj.) ili Još ćemo malo pričekati.

U drugim značenjima, koja ne moraju imati veze s vremenom, čestica još (ili još $i$ ) obično se dodaje riječima i/ili oblicima odnosno pojedinim članovima rečeničnoga ustrojstva i označuje isticanje nečega što se dodaje, što se pridružuje čemu postojećemu (usp. Halilović, Palić i Šehović 2010: 473), npr. Treba kupiti još kruha, Uradit ćemo još i to što predlažeš, Posudi mi još malo novaca.

13 U rječnicima se još u pravilu opisuje kao prilog (usp. ARj IV: 659) ili kao prilog i čestica (usp. Anić 1998: 376-377 i Šonje 2000: 418-419), ali mislim da se prilogom ta riječ (eventualno) može smatrati samo onda kad dolazi uz glagolske oblike odnosno uz predikate (npr. Još piše pjesme ili Još nismo završili). Kad međutim dolazi uz ostale vrste riječi ili skupove riječi odnosno uz pojedine članove rečeničnoga ustrojstva, npr. kad dolazi uz imenice (usp. Doći će još kolega Marić), uz brojeve, npr. Kupit ću još pet kilograma krumpira, uz priloge (usp. To smo riješili još jučer), uz prijedložno-padežne izraze (usp. Tako je odlučeno još na prošloj sjednici) ili uz komparative pridjeva i priloga (usp. Iduće godine nastao je još veći skandal ili Oni su prošli još gore) i sl., mislim da ga je opravdano smatrati isključivo česticom. 
Kako je upravo spomenuto značenje dodavanja svojstveno čestici još povezano i sa značenjem uspoređivanja, ${ }^{14}$ očekivano je da se ta čestica vrlo često rabi i uz komparative pridjeva ili priloga, npr. Čovik velike mudrosti $i$ još veće svetinje, Dobro gađa, još bolje pogađa (ARj IV: 661) ili Taj mu je roman još zanimljiviji od prethodnoga.

Čestica još (ili još i) u toj pojačajnoj službi ne mora se nužno odnositi ni na nešto dodano, nego općenito može isticati sadržaj riječi ili skupina ispred kojih stoji odnosno na koje se odnosi, npr. On je još i dobar kakvih ima, Ti si još jeftino prošao, Samo mi je još to trebalo.

Takvo pojačajno još osobito često dolazi uza zanijekane zamjenice odnosno zamjeničke pridjeve ili priloge, npr. Još nijedan Zagorec nije prodal vina, Još se nitko nije javio na oglas, Još ništa nije gotovo i sl.

Pojačajno značenje susrećemo i u ustaljenom izričaju još uvijek, s tim da u takvu izričaju kao intenzifikator ne služi još, nego (prilog odnosno čestica) uvijek služi zapravo za pojačavanje onoga što znači čestica još, a obje zajedno služe kao intenzifikatori obično kakve radnje ili kakva svojstva. Da je tako (tj. da je uvijek intenzifikator u odnosu na još, a da nije obrnuto), vidi se po tome što je u rečenicama s tim izričajem uvijek ispustivo, a još nije, usp. Još uvijek se nisu javili prema Još se nisu javili odnosno *Uvijek su se javili. Usp. i primjere tipa Još uvijek je onako tvrdoglav ili Još uvijek se nadamo da će biti bolje.

U starijem je jeziku čestica još mogla imati još šire značenje nego što ga ima u suvremenom jeziku. Tako se npr. ta čestica često rabila i u kontekstima u kojima bismo danas upotrijebili česticu čak, ${ }^{15}$ osobito kad je iza tako upotrijebljenoga još dolazio veznik da, npr. Bog hoće prostiti nam svaki grih, još da je koliko hoćeš težak ili Niti ovi mogu biti primljeni u službu crkovnu još i da budu odrišeni (ARj IV: 668).

Pojačajno još dolazi i u izrazima koji su se dijelom i frazeologizirali, kao što su npr. Još pitaš? ili Još kako! Ti izrazi kao potvrdni odgovori sugovornika u dijaloškoj formi obično označuju da se ono o čemu je riječ odnosno ono o čemu govornik pita je li se dogodilo, po mišljenju sugovornika, posve sigurno dogodilo, da je nesumnjivo, usp. A. Jeste li se tamo dobro proveli? B. Još pitaš!, ili A. Jesi li dobro naspavao? B. Još kako! ${ }^{16}$

\footnotetext{
14 Tako npr. već i samo dodavanje određene količine postojećoj čini tu količinu većom.

15 To možda može imati veze i s činjenicom da je čestica čak orijentalnoga podrijetla (turcizam) pa je kasnije ušla u uporabu.

16 Ovakvo je još zamjenjivo s nego, usp. Nego kako!
} 


\section{Čestica, veznik i konektor tek}

Čestica tek podrijetlom je iz perzijskoga jezika. Kao „balkanski turcizam" (Skok 1973: 454) došla je najprije u južne štokavske govore iz turskoga, u kojem znači samo ili samo ako. Zato nije čudno da nije zabilježena u starim hrvatskim rječnicima. ${ }^{17}$ Nema je ni u drugim slavenskim jezicima osim u bugarskom (v. ARj XVIII: 172). U starijem jeziku često je dolazila i u obliku teke, a u značenju čim odnosno tek što, npr. Teke primiš knjigu na rukama,/ Razvi barjak, s kopljem u ledini (usp. Škaljić 1989: 607).

U suvremenom jeziku čestica tek izrazito je pragmatične naravi. Antonimna je ovdje već opisanoj čestici već. Vezana je naime za vrijeme i označuje da se nešto događa, da se dogodilo ili da će se dogoditi kasnije nego što se očekuje, ponajprije kasnije nego što to očekuje govornik, npr. Tek sad mi to kažeš, Stigli su tek navečer, Javit će nam se tek sutra.

Javlja se također u značenju restriktora sinonimnoga restriktorima samo ili jedva, npr. Sad je Mari tek trinaest godina, To tek misli, ništa ne govori (ARj, nav. mj.).

$\mathrm{Na}$ razini složene rečenice ili na razini teksta tek se upotrebljava u značenju izuzimanja, isključivanja, npr. Jedva je disala, tek grčevito treptanje vjeđa odavalo je da ima u djevojci jošte života (usp. Barić i dr. 1995: 464), Govori tek da nešto kaže (usp. Halilović, Palić i Šehović 2010: 1321) ili Pust je: Tu ne raste ništa. Tek kamenje se golo plavi (Šimić 1988: 190).

Iza rastavnih konstrukcija i/ili konstrukcija koje označuju da se što suprotstavlja čemu drugome tek često ima jednu specifičnu nijansu konkluzivnoga značenja, naime značenja bliskoga onome kakvo imaju izrazi $u$ svakom slučaju, bilo kako bilo ili sl., npr. Poznavao ili ne poznavao pravne propise, tek postao je vrlo uspješan poslovni čovjek (usp. o tome Anić 1998: 1185 te Halilović, Palić i Šehović, nav. mj.).

Tek se može, posebice u starijem jeziku, rabiti i korelativno, kao tek ... a, ili tek ... ali, npr. Tek piperske puške zapucale, a turske su bule zakukale ili Tek počne jesti, al' eto ti jednoga pijetla (usp. ARj, nav. mj.).

Čestica tek udružuje se i s nekim subjunktorima te čini s njima složene veznike. To posebno često biva sa subjunktorima što, da i kad. U takvim vezničkim spojevima tek obično ima značenje restriktora, tj. sinonimno je $s$

17 Ima čak i mišljenja (npr. Ivana Popovića) da su Turci tu riječ primili iz „srpskoga jezika”, odnosno da je tek postalo prema tъkmo, tъčija, što je značilo „samo” (usp. ARj XVIII: 171). 
restriktorom samo. Dio takvih vezničkih spojeva ima vremensko značenje, značenje prijevremenosti (anteriornosti), posve blisko značenju vremenskih veznika pošto, nakon što ili čim, npr. Tek što ga ugleda, pobježe, Razgovarat ćemo o tome tek kad nam vratiš dug (usp. o takvim vremenskim rečenicama Silić i Pranjković 2005: 336-337).

U drugom dijelu konstrukcija s veznim sredstvima tek što i tek da susrećemo, posebno u starijem jeziku, i apstraktnije značenje, obično isključne naravi, npr. Kuću su platili vrlo skupo, tek što nisu morali uzimati kredit ili Lijepo zviždiš, tek da hoće ovce za tobom (ARj, nav. mj.). ${ }^{18}$

U suvremenom jeziku, posebno u razgovornome stilu, čest je i frazeologizirani izričaj tek tako, koji znači „olako, otprilike, preko volje, formalno” (usp. Anić 1998: 1185) i sl., npr. Tamo smo običavali zalaziti tek tako, da nam prođe vrijeme ili Danas su igrali tek tako, da se ne bi reklo kako bojkotiraju utakmicu.

Zaključno bi se moglo reći da i ova raščlamba gramatičkih i pragmatičkih svojstava u mnogo čemu sličnih „malih riječi” nego, no, već, još i tek ${ }^{19}$ zorno pokazuje kako je uloga takvih riječi i u pojedinim sintaktičkim konstrukcijama i u komunikaciji vrlo važna te da takve riječi, posebice u službi čestica, veznika i konektora, zaslužuju punu pozornost i onih proučavatelja koji se bave ustrojstvom pojedinih sintaktičkih konstrukcija i onih koje primarno zanimaju pragmatički aspekti takvih konstrukcija i/ili pojedinih tekstova u kojima se takve konstrukcije susreću.

\section{Literatura}

Anić, Vladimir ('1998) Rječnik hrvatskoga jezika, Novi Liber, Zagreb.

Badurina, Lada (2008) Između redaka. Studije o tekstu i diskursu, Hrvatska sveučilišna naklada i Izdavački centar Rijeka, Zagreb - Rijeka.

Badurina, Lada i Nikolina Palašić (2012) „Pragmatika veznih sredstava”, Sarajevski filološki susreti I. Zbornik radova (knjiga I), Bosansko filološko društvo, Sarajevo, str. 252-265.

Barić, Eugenija, Mijo Lončarić, Dragica Malić, Slavko Pavešić, Mirko Peti, Vesna Zečević i Marija Znika (1995) Hrvatska gramatika, Školska knjiga, Zagreb.

\footnotetext{
18 Usp. i navedeni primjer Govori tek da nešto kaže.

19 Sličnost među tim riječima, kao što se moglo vidjeti, osobito dolazi do izražaja u nekim aspektima poredbenih i/ili suprotnih značenja.
} 
Bulić, Halid (2013) „Veznici i junktori u bosanskom jeziku - teorijsko i terminološko razgraničenje”, Bosnistika plus, I/1, Institut za bosanski jezik i književnost u Tuzli, Tuzla, str. 31-47.

Halilović, Senahid, Ismail Palić i Amela Šehović (2010) Rječnik bosanskoga jezika, Filozofski fakultet, Sarajevo.

Kordić, Snježana (2002) Riječi na granici punoznačnosti, Hrvatska sveučilišna naklada, Zagreb.

Kovačević, Miloš (1987) „Gradacione konstrukcije u Vukovom i današnjem jeziku”, Zbornik radova o Vuku Stefanoviću Karadžiću, Sarajevo, str. 225-236.

Kunzmann-Müller, Barbara (1993) „Konjunktionen in slavischen Sprachen. Synchrone und diachrone Aspekte", Wiener slawistischer Almanach, 31, Wien, str. 245-257.

Palić, Ismail (2003) „O klasifikaciji nepromjenjivih riječi u bosanskome jeziku”, Pismo. Časopis za jezik i književnost, I/1, Bosansko filološko društvo, Sarajevo, str. 93-102.

Pranjković, Ivo (2008) „Vezničko i nevezničko da u hrvatskome jeziku”, Riječki filološki dani 7. Zbornik radova, Rijeka, str. 505-515.

Pranjković, Ivo (2010) „Zamjenica, prilog, čestica i veznik što”, Riječki filološki dani 8. Zbornik radova, Rijeka, str. 401-408.

Pranjković, Ivo (2013) Gramatička značenja, Matica hrvatska, Zagreb.

Pranjković, Ivo (2015) „O riječima sam i sâmo”, Njegoševi dani 5. Zbornk radova, Filozofski fakultet Nikšić, Nikšić, str. 295-301.

Pranjković, Ivo (2016) Gramatika u riječima i riječi u gramatici, Matica hrvatska, Zagreb.

Rječnik hrvatskoga ili srpskoga jezika (ARj), I-XXIII, JAZU, Zagreb, 1880/1882-1976.

Silić, Josip (2005) „Samoznačne (autosemantične) i suznačne (sinsemantične) vrste riječi u hrvatskome jeziku", Zagrebačka slavistička škola. Zbornik radova 2004, Zagreb, str. 13-18.

Silić, Josip i Ivo Pranjković (2005) Gramatika hrvatskoga jezika za gimnazije i visoka učilišta, Školska knjiga, Zagreb.

Skok, Petar (1971, 1972, 1973) Etimologijski rječnik hrvatskoga ili srpskoga jezika, I-III, Zagreb.

Šimić, Antun Branko (1988) Djela 1, prir. Nedjeljko Mihanović, August Cesarec, Zagreb. 
Škaljić, Abdulah (61989) Turcizmi u srpskohrvatskom jeziku, Svjetlost, Sarajevo. Šonje, Jure (gl. ur.) (2000) Rječnik hrvatskoga jezika, Leksikografski zavod Miroslav Krleža i Školska knjiga, Zagreb.

Tekavčić, Pavao (1989) „Prema kontrastivnoj pragmatici tzv. 'čestica' u hrvatskom ili srpskom i talijanskom jeziku”, Rad JAZU, knj. 427, Zagreb, str. 127-194.

Vukojević, Luka (1986) „O razlici između ali i nego suprotnih veznika”, Suvremena metodika nastave hrvatskoga ili srpskoga jezika, 2-3, Zagreb, str. 130-142.

Vukojević, Luka i Lana Hudeček (2007) „Podrijetlo, ustrojstvo, funkcija i normativni status složenih veznika i vezničkih skupina", Sintaktičke kategorije. Zbornik radova s međunarodnim sudjelovanjem Hrvatski sintaktički dani, Osijek, str. 283-335.

\section{SUMMARY}

Ivo Pranjković

\section{ON NEGO, NO, VEĆ, JOŠ AND TEK}

In this paper we focus on the grammatical and pragmatic properties and the origin, use and meanings of "small words" nego, no, već, još and tek that are similar in many ways. We pay special attention to the analysis of their use in comparison (e.g. Bolje je nego prije) and in the pragmatic senses of temporal nature, especially in those senses that denote events that took place before (e.g. Već su stigli or Još nisu stigli) or after the speaker expected them to happen (e.g. Tek su danas doputovali). Finally, we also focus on the role of these words as conjunctions used in contrast clauses (e.g. Nismo im pisali, već smo ih nazvali telefonom) or as text connectors (e.g. Tu ne raste ništa. Tek kamenje se golo plavi).

Keywords: grammaticalized words; pragmatic properties; origin; comparison; temporal senses; contrast 